\title{
DSS IN NUMBERS
}

\author{
Florin Gheorghe FILIP ${ }^{\mathrm{a}}$, Ana-Maria SUDUC ${ }^{\mathrm{b}}$, Mihai BÎZOI ${ }^{\mathrm{b}}$ \\ ${ }^{a}$ Romanian Academy: BAR, INCE, and ICI, Bucharest, Romania \\ ${ }^{\mathrm{b}}$ Valahia University of Targoviste, Targoviste, Romania
}

Received 27 October 2013; accepted 05 November 2013

\begin{abstract}
Decision Support Systems (DSS) have evolved in time, influenced by technological and organizational developments. The scientists' interest for DSS has increased over the years and the use of this type of systems has spread in all domains of activity. The paper presents the results of a literature search, made in September 2013, regarding the Decision Support Systems evolution as it is reflected in three scientific databases (ScienceDirect, IEEE Xplore Digital Library and ACM Digital Library). The aim of this research is to present the evolution in time of the published DSS research materials and to test the usefulness and relevance, for the topic searched, of the information provided by the above mentioned databases.
\end{abstract}

Keywords: decision support systems, publications, scientific databases, relevant topics.

Reference to this paper should be made as follows: Filip, F. G.; Suduc, A.-M.; Bîzoi, M. 2014. DSS in numbers, Technological and Economic Development of Economy 20(1): 154-164.

JEL Classification: L86.

\section{Introduction}

In Filip (2008), a DSS is defined as "an anthropocentric, adaptive and evolving information system which is meant to implement the functions of a team of assistants that would otherwise be necessary to help the decision-maker to overcome his/her limits and constraints he/she may encounter when trying to solve complex and complicated decision problems that count". The DSS concept was anticipated by the idealized vision of Licklider (1960) over the "precognitive" man-computer systems, which were meant to "[...] enable man and computers to co-operate on making decisions and control complex situations [...]". According to McCosh (2002), the term was first articulated by M. Scott-Morton in a seminar held in February 1964. As many

Corresponding author Florin Gheorghe Filip

E-mail:ffilip@acad.ro 
new concepts, DSS was received with enthusiasm by a part of academia community and industry people. For example, Wagner (1981), a pioneer in the DSS domain (Power 2013), hailed "the new school of thought called DSS". At the same time, the term itself and especially its usage were controversial. For example, Bonczek et al. (1984), important contributors to the advancement of the DSS movement, noticed that the term was abused as a "new label" placed on various software products, in order to obtain a competitive advantage. Moreover, Naylor (1982) claimed DSS is a "redundant term" meant to describe a subsystem of MIS (Management Information System) and it was not based on a conceptual framework. Ever since, both conceptual advances and practical applications have confirmed the statement of Vazsonyi (1982) that "DSS satisfies a real need and there is a market for it". The remaining part of this paper aims at supporting the above statement with respect to research activities as reflected in the scientific literature to be found on the Internet.

According to Lawrence (2001), "the volume of scientific literature typically far exceeds the ability of scientists to identify and utilize all relevant information in their research". Many international scientific databases offer, on each search performed, a wide range of information (topics, authors, publications, etc.) which may help the scientists to find the information they need for their work. According to Suduc et al. (2010), this information is, usually, quite comprehensive, to gain a quantitative wide perspective on the research activity corresponding to the terms used to perform the search. The use of this type of information provided by the scientific databases is especially helpful to complete or to facilitate the structuring various authors' knowledge in certain research fields.

The paper presents updated information and a comparison with the data published in Suduc et al. (2010). Therefore, in the sequel, there are presented figures of the research production in the DSS research field, as they are reflected in three international scientific databases: ScienceDirect, IEEE Xplore Digital Library and ACM Digital Library. The specific aim of this study is to identify the evolution in time of the DSS research field, major research trends (research topics), the most important DSS publications and so on.

\section{Method}

The DSS concept, launched before the existence of PCs, and the corresponding research area (Alter 2002) have evolved in a strong relation with the information systems developments and have diversified over the years. The development of the web technologies has radically transformed the design, development, implementation and the deployment of the DSS (Bhargava et al. 2007). At present, the term Decision Support Systems designates a wide class of systems which includes various types of technologies and aims at supporting the decision-making activities.

To evaluate the evolution of the domain, a set of numerical data related to the DSS materials published, are presented in the sequel, since the beginning of the DSS research, the publications with the greatest number of DSS materials and topics/subjects/keywords of the DSS materials, as they are reflected in three relevant scientific databases, in comparison with similar data obtained in 2010 . The paper aims to identify if the data provided by the scientific databases analysed are useful for future authors and relevant for the research field. 
One particular purpose of this study is to make a comparison between the data obtained in November 2010 and those from September 2013, in order to identify the DSS research evolution during the years, by analysing the numbers of the DSS published materials and a series of related data. The method applied involved several queries on three international research databases: ScienceDirect, IEEE Xplore Digital Library and ACM Digital Library.

The DSS-related search terms that were utilised to obtain a wide perspective on the DSS research field are, in both analyses (2010 and 2013): "decision support system", "decision system", "decision tool", "decision making system" and the plural of these words. These concepts were considered to be the most commonly used by researchers to refer to this type of systems.

Searches were made on all the materials (articles, books, reports, etc.), contained in the selected scientific databases, that included at least one of the above concepts in the title, abstract or keywords. The decision to search the selected terms only within the title, abstract and keywords was made after noticing that general searches (within any field) also returned articles which were not relevant for DSS research area. After all, the list of search terms was selected, so as to surely obtain DSS relevant articles.

Since decision support systems are now viewed as a wide range of specific, but very diversified information systems, many others terms, that are relevant for DSS research area (e.g. data warehousing, OLAP, data mining or business intelligence), were not considered for this research.

The information presented in this paper about publication titles or publication year was obtained by using filtering build-in options of the scientific databases.

\section{Results}

To update the results of the search completed on the 12th of November 2010 (Suduc et al. 2010), a new search was made at the beginning of September 2013. The returned results indicate a significantly higher number of published materials registered in the selected scientific data bases, both expressed in absolute values (Fig. 1) and relative increase ratios (Table 1). Those global results will be refined and commented in the sequel.

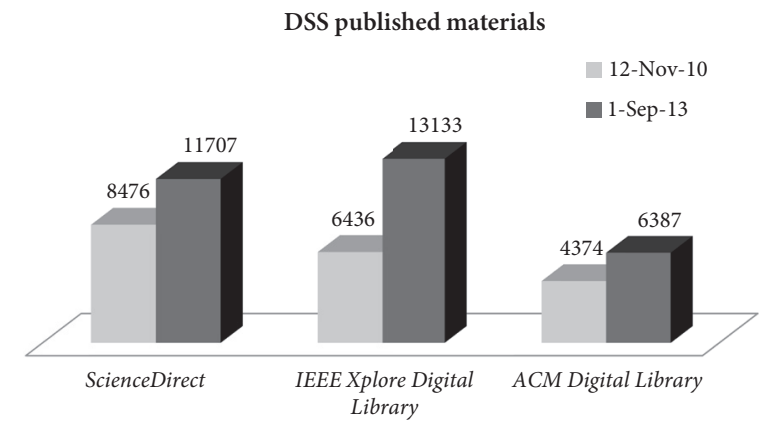

Fig. 1. Numbers of DSS materials in ScienceDirect, IEEE and ACM on the 12th of November 2010 and the 1st of September 2013 
Table 1. Numbers of DSS materials indexed in international databases - comparison November 2010 - September 2013

\begin{tabular}{lccc}
\hline \multirow{2}{*}{ Databases } & \multicolumn{3}{c}{ Published Materials } \\
\cline { 2 - 4 } & $\begin{array}{c}\text { September 2013 } \\
\text { [Absolute values] }\end{array}$ & $\begin{array}{c}\text { November 2010 } \\
\text { [Absolute values] }\end{array}$ & Increase [\%] \\
\hline ScienceDirect & 11707 & 8476 & 38,12 \\
\hline IEEE Xplore Digital Library & 13133 & 6436 & 104,06 \\
\hline ACM Digital Library & 6387 & 4374 & 46,02 \\
\hline
\end{tabular}

\subsection{Evolution per decade}

The evolution per decades of the DSS published materials shows an almost exponential increasing interest for this type of systems. Figures 2, 3 and 4 present the evolution of DSS materials, per decade, until 2010, in ScienceDirect, IEEE Xplore Digital Library and ACM Digital Library, respectively, as it was reported in 2010 and 2013. The databases reported also a wide number of DSS materials published between 2011 and 2013 (1236 in ACM Digital Library, 3100 in Science Direct and 3420 in IEEE Xplore Digital Library).

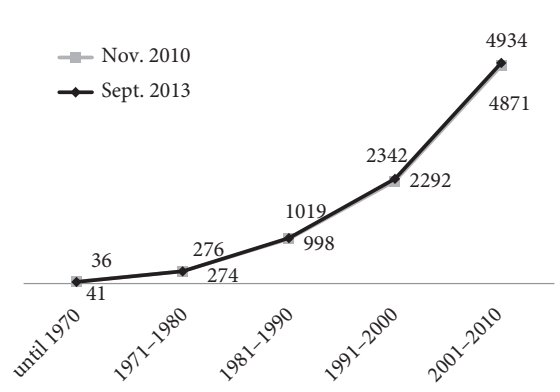

Fig. 2. Evolution, per decade, of numbers of DSS materials indexed in ScienceDirect

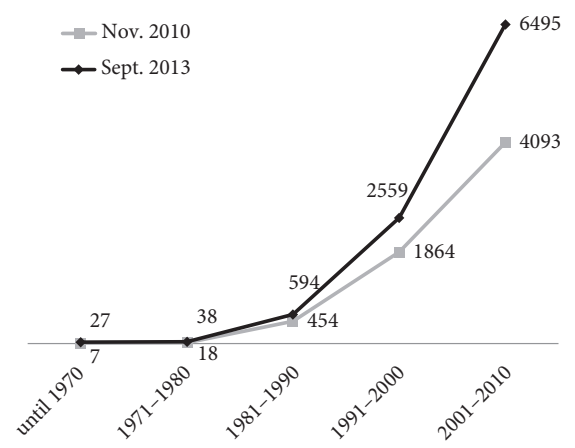

Fig. 3. Evolution, per decade, of numbers of DSS materials indexed in IEEE Xplore Digital Library

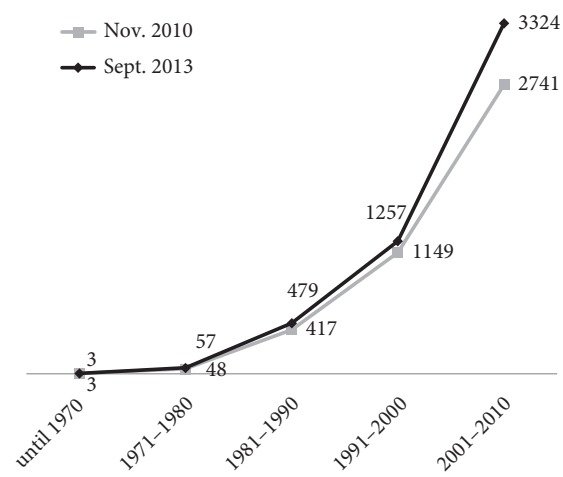

Fig. 4. Evolution, per decade, of numbers of DSS materials indexed in ACM Digital Library 
It is interesting to notice that the databases were updated not only with newly published materials, but also with materials which were published in the past, since the beginning of the reported period. For example, in ScienceDirect there were reported, in 2013 compared to 2010, 15 more articles published before 1970 and, in IEEE Xplore Digital Library, 20 articles.

The dynamics of the scientific databases content includes not only additions, but also removals. For example, in Science Direct, in 2013, there were fewer articles published before 1970 than in 2010.

\subsection{Yearly production}

Figure 5 presents a comparison between the results obtained in 2010 and 2013, related to the evolution of the DSS published materials over the last 10 years and 13 years, respectively.

The results of this comparison indicate that:

1. The DSS research production kept the ascendant trend;

2. In IEEE Xplore Digital Library, the indexing rate of the DSS materials is higher than in Science Direct (unlike 2010, in 2013, the results show that the IEEE Xplore Digital Library line is above the Science Direct line, with a higher number of published materials per year);

3. ACM Digital Library, compared to Science Direct and IEEE Xplore Digital Library, reported a slow decrease of DSS articles over the last three years. This might be caused by a lower indexing rate. The authors of this paper consider that this result has another explanation than a lower interest of scientists in this research area (e.g. a low indexing rate of the ACM Digital Library).

\subsection{Relevant topics}

In 2010, all the three searched scientific databases included a refinement criterion by "topics" (ScienceDirect), "subject" (IEEE Xplore Digital Library) or by "discovered terms" (ACM Digital Library), showing a list of the most frequently encountered topics/subjects/discovered terms. These lists were quite useful in discovering the main research topics in DSS area. A search performed per decades (Suduc et al. 2010) indicated the evolution of scientists' interest on decision support systems, which were quite useful for gaining a wide perspective on DSS evolution in time. Unfortunately, in 2013, only Science Direct still included such an option, the other two databases gave up providing this type of search refinement.

In 2010, the several main topics/most used terms identified by the databases were: "decision support”, "decision support systems", "DS”, "decision making”, "expert systems”, "group decision support systems", "health care", "neural networks", "supply chain". These identified terms indicate several DSS key terms and also some DSS application fields.

Arnott and Pervan (2008), who carried out a long-term project meant to critically analyse the academic field of decision support systems based on the content analysis of 1093 DSS articles published in 14 major journals from 1990 to 2004, published a list of major DSS subfields, such as: "personal decision support systems", "group support systems", "negotiation support systems", "intelligent decision support systems", "knowledge management-based DSS", "data warehousing", "enterprise reporting", "analysis systems". 
a) Numbers of DSS published materials between 2001-2010

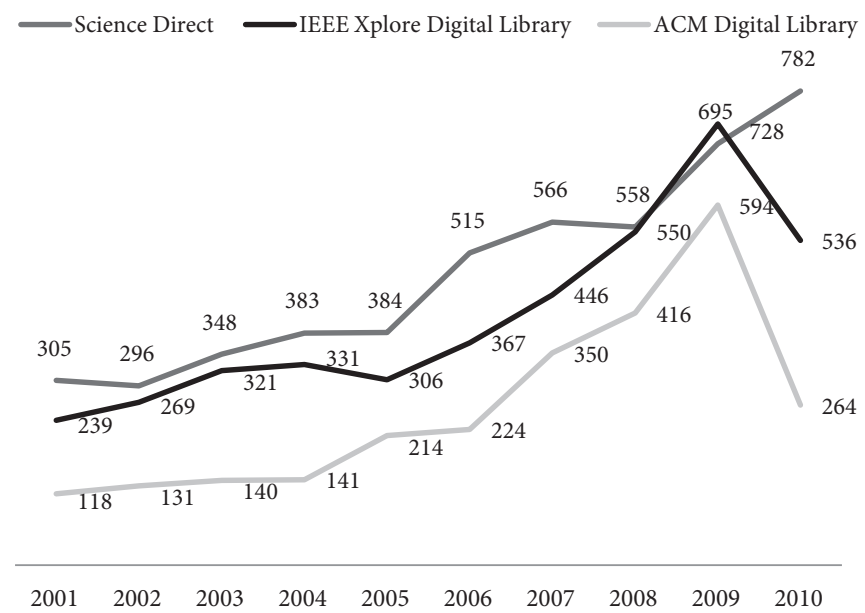

b)

Numbers of DSS published materials between 2001-2013

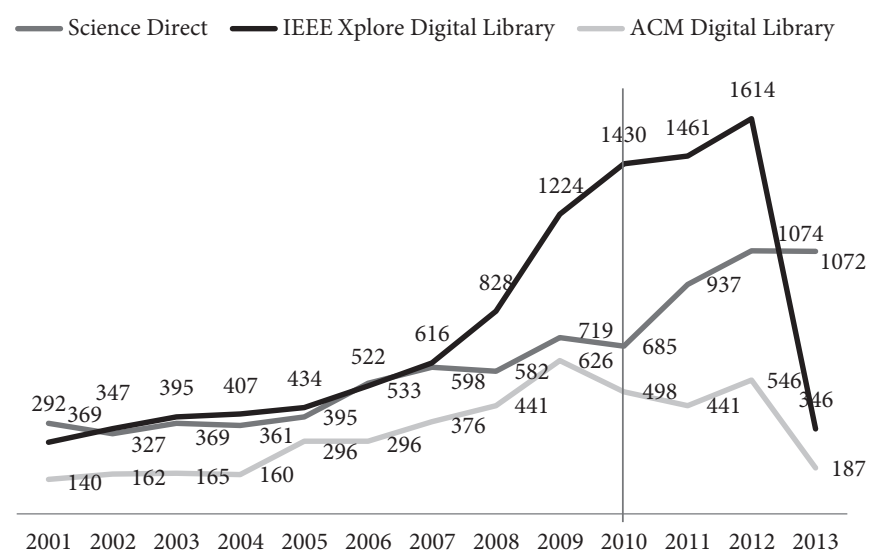

Fig. 5. DSS research yearly production: a) data obtained in 2010); b) data obtained in 2013

Sub-searches in the databases by these subfields and the main DSS terms/topics/subjects identified in 2010, led to the results presented in Table 2. The order of the searched terms is the occurrence order of these terms, from the most used to the less used.

The results show that the most used terms within the articles in the DSS field are:

- "decision-making" (93.65\% articles in Science Direct include this term, 26.24\% in IEEE Xplore Digital Library and $44.17 \%$ in ACM Digital Library); 
- "decision support systems" (25,07\% articles in Science Direct, 90.09\% in IEEE Xplore Digital Library and 59.89\% in ACM Digital Library).

Other quite often encountered terms are:

- "expert systems", that is a very popular DSS thread from about 1965 to the mid-1990s (Power 2007);

- "management systems", which is not a surprising issue, since most of decision support systems are meant to support managers;

- "health care", that is a very important field where there is a growing interest in the use of DSS (named clinical decision support systems) (Osheroff et al. 2007) which have been shown to improve both patient outcomes and the cost of care (Berner, La Lande 2007).

Table 2. Main topics

\begin{tabular}{lccc}
\hline & Science Direct & IEEE & ACM \\
\hline TOTAL No. of articles & $\mathbf{1 1 7 0 7}$ & $\mathbf{1 3 1 3 3}$ & $\mathbf{6 3 8 7}$ \\
\hline decision-making & 10964 & 3446 & 2821 \\
\hline decision support systems & 2935 & 11832 & 3825 \\
\hline expert systems & 2419 & 883 & 1257 \\
\hline management systems & 2195 & 377 & 427 \\
\hline health care & 1533 & 409 & 453 \\
\hline supply chain & 885 & 200 & 332 \\
\hline group decision support systems & 296 & 586 & 278 \\
\hline data warehouse & 220 & 224 & 309 \\
\hline business intelligence & 144 & 102 & 185 \\
\hline intelligent decision support systems & 181 & 54 & 139 \\
\hline
\end{tabular}

The search of the other terms, such as "group decision support systems", "data warehouse", "business intelligence" and "intelligent decision support systems", within the initial results, although relevant for the DSS research field, didn't return very good results (less than $8 \%$ of the total number of DSS materials from the analysed scientific databases). An explanation might be that these terms are categories which are often used in other forms. For example, for "group decision support systems" other terms, such as "group support systems" or "electronic meeting systems", are used.

\subsection{Relevant publications}

Table 3 presents the first ten publications (journals/books/proceedings) indicated, both in 2010 and in 2013, by the scientific databases, as containing the highest number of DSS research papers. The results show that, comparing with 2010 study results, the top ten publications partially changed in 2013. The least changed is the top ten in ScienceDirect which has 8 publications in common with the one from 2010. The ACM Digital Library top has 6 publications in common and IEEE Xplore Digital Library, 5 publications. Also, it can be noticed that all the numbers obtained in 2013 are higher, compared to the ones obtained in 2010. 
The journal with the highest number of articles is Decision Support System, with 978 articles in ACM Digital Library (the first place in top ten) and 351 articles in ScienceDirect (the third place). The second publication with the highest number of DSS articles indexed in the selected scientific databases is Expert Systems with Applications, with 466 articles indexed in ScienceDirect and 406 in ACM Digital Library. Others publications in top ten reported both by ScienceDirect and ACM Digital Library are: Information and Management, Computers and Industrial Engineering and Environmental Modelling \& Software.

Table 3. The publications which include the highest number of DSS materials

\begin{tabular}{|c|c|c|c|c|c|c|c|c|}
\hline \multicolumn{3}{|c|}{ ScienceDirect } & \multicolumn{3}{|c|}{ IEEE Xplore Digital Library } & \multicolumn{3}{|c|}{ ACM Digital Library } \\
\hline Journal/Book title & $\begin{array}{l}\text { No. } \\
2010\end{array}$ & $\begin{array}{l}\text { No. } \\
2013\end{array}$ & Journal/Book title & $\begin{array}{l}\text { No. } \\
2010\end{array}$ & $\begin{array}{c}\text { No. } \\
2013\end{array}$ & Journal/Book title & $\begin{array}{l}\text { No. } \\
2010\end{array}$ & $\begin{array}{l}\text { No. } \\
2013\end{array}$ \\
\hline $\begin{array}{l}\text { Expert Systems } \\
\text { with Applications }\end{array}$ & 294 & 466 & $\begin{array}{l}\text { IEEE Transactions } \\
\text { on Systems, Man and } \\
\text { Cybernetics }\end{array}$ & 61 & 89 & $\begin{array}{l}\text { Decision Support } \\
\text { Systems }\end{array}$ & 593 & 978 \\
\hline $\begin{array}{l}\text { European Journal } \\
\text { of Operational } \\
\text { Research }\end{array}$ & 353 & 386 & $\begin{array}{l}\text { International Conference } \\
\text { on Computer Distributed } \\
\text { Control and Intelligent } \\
\text { Environmental } \\
\text { Monitoring (CDCIEM), } \\
2011\end{array}$ & - & 87 & $\begin{array}{l}\text { Expert Systems } \\
\text { with Applications: } \\
\text { An International } \\
\text { Journal }\end{array}$ & 140 & 406 \\
\hline $\begin{array}{l}\text { Decision Support } \\
\text { Systems }\end{array}$ & 302 & 351 & $\begin{array}{l}\text { 19th International } \\
\text { Conference on Microwave } \\
\text { Radar and Wireless } \\
\text { Communications } \\
\text { (MIKON), } 2012\end{array}$ & - & 82 & $\begin{array}{l}\text { Information and } \\
\text { Management }\end{array}$ & 97 & 117 \\
\hline $\begin{array}{l}\text { Computers \& } \\
\text { Industrial } \\
\text { Engineering }\end{array}$ & 106 & 142 & $\begin{array}{l}\text { World Congress on } \\
\text { Information and } \\
\text { Communication } \\
\text { Technologies (WICT), } \\
2012\end{array}$ & - & 81 & Interfaces & 70 & 111 \\
\hline $\begin{array}{l}\text { International } \\
\text { Journal of } \\
\text { Production } \\
\text { Economics }\end{array}$ & 119 & 142 & $\begin{array}{l}\text { International Conference } \\
\text { on Communications, } \\
\text { Devices and Intelligent } \\
\text { Systems (CODIS), } 2012\end{array}$ & - & 76 & $\begin{array}{l}\text { Environmental } \\
\text { Modelling \& } \\
\text { Software }\end{array}$ & - & 67 \\
\hline $\begin{array}{l}\text { Information \& } \\
\text { Management }\end{array}$ & 132 & 140 & $\begin{array}{l}\text { IEEE Transactions on } \\
\text { Information Technology } \\
\text { in Biomedicine }\end{array}$ & 52 & 67 & MIS Quarterly & - & 63 \\
\hline $\begin{array}{l}\text { Fuzzy Sets and } \\
\text { Systems }\end{array}$ & 132 & 135 & $\begin{array}{l}\text { Proceedings of the } \\
\text { 23rd Annual Hawaii } \\
\text { International Conference } \\
\text { on System Sciences, } 1990\end{array}$ & 48 & 54 & $\begin{array}{l}\text { Knowledge-Based } \\
\text { Systems }\end{array}$ & - & 92 \\
\hline $\begin{array}{l}\text { Agricultural } \\
\text { Systems }\end{array}$ & 115 & 134 & $\begin{array}{l}\text { Proceedings of the } \\
\text { Twenty-Fourth Annual } \\
\text { Hawaii International } \\
\text { Conference on System } \\
\text { Sciences, } 1991\end{array}$ & 49 & 54 & $\begin{array}{l}\text { Computers } \\
\text { and Industrial } \\
\text { Engineering }\end{array}$ & - & 89 \\
\hline
\end{tabular}


Continued Table 3

\begin{tabular}{|c|c|c|c|c|c|c|c|c|}
\hline \multicolumn{3}{|c|}{ ScienceDirect } & \multicolumn{3}{|c|}{ IEEE Xplore Digital Library } & \multicolumn{3}{|c|}{ ACM Digital Library } \\
\hline Journal/Book title & $\begin{array}{l}\text { No. } \\
2010\end{array}$ & $\begin{array}{l}\text { No. } \\
2013\end{array}$ & Journal/Book title & $\begin{array}{l}\text { No. } \\
2010\end{array}$ & $\begin{array}{l}\text { No. } \\
2013\end{array}$ & Journal/Book title & $\begin{array}{l}\text { No. } \\
2010\end{array}$ & $\begin{array}{l}\text { No. } \\
2013\end{array}$ \\
\hline $\begin{array}{l}\text { Journal of } \\
\text { Environmental } \\
\text { Management }\end{array}$ & - & 126 & $\begin{array}{l}\text { 2nd International } \\
\text { Conference on } \\
\text { Consumer Electronics, } \\
\text { Communications and } \\
\text { Networks (CECNet), } 2012\end{array}$ & - & 54 & $\begin{array}{l}\text { Computers and } \\
\text { Electronics in } \\
\text { Agriculture }\end{array}$ & 36 & 89 \\
\hline $\begin{array}{l}\text { Environmental } \\
\text { Modelling \& } \\
\text { Software }\end{array}$ & - & 105 & $\begin{array}{l}\text { IEEE Transactions } \\
\text { on Systems, Man and } \\
\text { Cybernetics, Part A: } \\
\text { Systems and Humans }\end{array}$ & 42 & 53 & $\begin{array}{l}\text { Journal of Medical } \\
\text { Systems }\end{array}$ & 29 & 84 \\
\hline $\begin{array}{l}\text { Social Science \& } \\
\text { Medicine }\end{array}$ & 85 & - & $\begin{array}{l}\text { HICSS-32. Proceedings of } \\
\text { the 32nd Annual Hawaii } \\
\text { International Conference } \\
\text { on System Sciences, } 1999\end{array}$ & 47 & - & $\begin{array}{l}\text { ACM SIGMIS } \\
\text { Database }\end{array}$ & 36 & 52 \\
\hline Omega & 82 & - & $\begin{array}{l}\text { Vol.III: Decision } \\
\text { Support and Knowledge } \\
\text { Based Systems Track, } \\
\text { Proceedings of the } \\
\text { 22nd Annual Hawaii } \\
\text { International Conference } \\
\text { on System Sciences, } 1989\end{array}$ & 45 & 48 & $\begin{array}{l}\text { Computers and } \\
\text { Operations } \\
\text { Research }\end{array}$ & 28 & 41 \\
\hline- & - & - & $\begin{array}{l}\text { IEEE Transactions on } \\
\text { Systems, Man, and } \\
\text { Cybernetics, Part C: } \\
\text { Applications and Reviews }\end{array}$ & 39 & 45 & $\begin{array}{l}\text { Proceedings of } \\
\text { the 28th Hawaii } \\
\text { International } \\
\text { Conference on } \\
\text { System Sciences }\end{array}$ & 26 & 26 \\
\hline- & - & - & $\begin{array}{l}\text { IEEE International } \\
\text { Conference on Systems, } \\
\text { Man, and Cybernetics, } \\
\text { 1997. 'Computational } \\
\text { Cybernetics and } \\
\text { Simulation, } 1997\end{array}$ & 38 & - & $\begin{array}{l}\text { Management } \\
\text { Science }\end{array}$ & 22 & $\begin{array}{c}28 \\
-\end{array}$ \\
\hline- & - & - & $\begin{array}{l}\text { Vol.III. Decision } \\
\text { Support and Knowledge } \\
\text { Based Systems Track, } \\
\text { Proceedings of the } \\
\text { 21st Annual Hawaii } \\
\text { International Conference } \\
\text { on System Sciences, } 1988\end{array}$ & 37 & - & & & \\
\hline
\end{tabular}

The fact that two databases returned five common publications in top 10 leads us to the conclusion that these reported journals are really relevant for the DSS research field.

\section{Conclusions}

The results presented in this paper indicate, by comparison with similar data previously published in Suduc et al. (2010), the steadily increasing interest in the research area of decision support systems, the research trends over the last decade, some DSS main concepts and 
application domains, the journals and conference proceedings with the highest number of DSS research papers in DSS research field. These data are presented as they are reflected by three scientific databases: ScienceDirect, IEEE Xplore Digital Library and ACM Digital Library and analysed so as to determine their relevance for DSS field.

W. T. Lord Kelvin (1824-1906), the famous British mathematician, physicist and engineer, firmly stated in its lecture entitled "Electrical Units of Measurements", held on $13^{\text {th }}$ May 1883, "I often say that when you can measure what you are speaking about and express it in numbers, you know something about it; but when you cannot express it in numbers, your knowledge is of a meagre and unsatisfactory kind" (Shell 1998). However, there are also other opinions about the compulsoriness of expressing the knowledge in numbers. Many centuries ago, Marcus Tullius Cicero (106-48 B.C.), a reputed Roman orator, wisely stated (Cicero 1913): "Non enim numero haec judicantur, sed pondere" ("The number does not matter, the quality does").

The authors of this paper think that, even though the results presented above have a certain indicative relevance, a deeper analysis of the published paper content may bring in even more useful insights for the researcher. Since the DSS domain is already very broad and the results reported are quite diversified, sectorial studies addressing specific application domains may be feasible, useful, usable and eventually used.

\section{References}

Alter, S. 2002. A work system view of DSS in its fourth decade, in Eighth Americas Conference on Information Systems, 150-156.

Arnott, D.; Pervan, G. 2008. Eight key issues for the decision support systems discipline, Decision Support Systems 44(3): 657-672. http://dx.doi.org/10.1016/j.dss.2007.09.003

Berner, E. S.; La Lande, T. J. 2007. Overview of clinical decision support systems, in E. S. Berner (Ed.). Clinical Decision Support Systems. New York: Springer Science + Business Media, LLC, 3-22.

Bhargava, H. K.; Power, D. J.; Daewon, S. 2007. Progress in web-based decision support technologies, Decision Support Systems 43(4): 1083-1095. http://dx.doi.org/10.1016/j.dss.2005.07.002

Bonczek, R. H.; Holsapple, C. W.; Whinston, A. 1984. Developments in decision support systems, Advances in Computer 23: 141-175. http://dx.doi.org/10.1016/S0065-2458(08)60464-7

Cicero, M. T. 1913. De Oficiis. Loeb Edition (Miller Walter translation), University Press, Cambridge. 79 p.

Filip, F. G. 2008. Decision support and control for large-scale complex systems, Annual Reviews in Control 32(1): 61-70. http://dx.doi.org/10.1016/j.arcontrol.2008.03.002

Lawrence, S. 2001. Online or invisible?, Nature 411(6837): 521. http://dx.doi.org/10.1038/35079151

Licklider, J. C. R. 1960. Man-computer symbiosis, IRE Transactions on Human Factors in Electronics-HFE 1(1): 4-10. http://dx.doi.org/10.1109/THFE2.1960.4503259

McCosh, A. 2002. Comments on 'A Brief History of DSS'. E-mail to D. Power, Oct 3, 2002, in Power. 2007.

Naylor, T. H. 1982. Decision support systems or whatever happened to MIS, Interfaces 12(4): 92-94. http://dx.doi.org/10.1287/inte.12.4.92

Osheroff, J. A.; Teich, J. M.; Middleton, B.; Steen, E. B.; Wright, A.; Detmer, D. E. 2007. A roadmap for national action on clinical decision support, Journal of the American Medical Informatics Association 14(2): 141-145. http://dx.doi.org/10.1197/jamia.M2334

Power, D. J. 2007. A brief history of decision support systems, Version 2.8 [online], [cited 20 September 2013]. Available from Internet: http://DSSResources.COM/history/dsshistory.html 
Power, D. J. 2013. Decision Support Pioneers [online], [cited 20 September 2013]. Available from Internet: http://dssresources.com/history/pioneers/pioneerslist.html

Shell, R. R. 1998. Performance measure and compensation, in Stellman, J. M. (Ed.). Ecyclopaedia of occupational health and safety. $4^{\text {th }}$ ed. Geneva: ILO. $1992 \mathrm{p}$.

Suduc, A.-M.; Bizoi, M.; Cioca, M.; Filip, F. G. 2010. Evolution of decision support systems research field in numbers, Informatica Economica 14(4): 78-86.

Vazsonyi, A. 1982. Decision support systems: computer literacy and electronic models, Interfaces 12(1): 74-78. http://dx.doi.org/10.1287/inte.12.1.74

Wagner, R. G. 1981. Decision support systems: the real substance, Interfaces 11(2): 77-80. http://dx.doi.org/10.1287/inte.11.2.77

Florin Gheorghe FILIP took his MSc and PhD in Control Engineering from the TU "Politehnica" of Bucharest. In 1991 he was elected as a Member of the Romanian Academy (RA). He has been a Scientific Researcher at the National R\&D Institute in Informatics (ICI) of Bucharest since 1970. Currently, he is a Part-Time Researcher at the National Institute of Economic Researches (INCE) of the RA, also the Director of the Library of the Academy. He was elected as Vice-President of RA in 2000 and re-elected in 2002 and 2006. His main scientific interests include large-scale systems, decision support systems, technology management and foresight.

Ana-Maria SUDUC took her PhD in Computer Science from Romanian Academy. Currently, she is a Lecturer at Automatic Control, Informatics and Electrical Engineering Department, Valahia University of Targoviste. Her current research interests include interfaces for decision support systems, group decision support systems, and web interfaces.

Mihai BIZOI took his PhD in Computer Science from Romanian Academy. Currently, he is a Lecturer at Automatic Control, Informatics and Electrical Engineering Department, Valahia University of Targoviste. His current research interests include communications-driven decision support systems, group decision support systems, and web collaborative technologies. 